\title{
New and Interesting Records of South African Fungi. Part iii.*
}

\author{
By
}

P. H. B. Talbot.

\section{Schizostoma laceratum Ehrenb. ex Lev.}

This species has previously been recorded only from equatorial Africa, Australia, India (Cunningham, 1944) and California (Lloyd, 1923). Mr. J. P. H. Acocks, who has a remarkable flair for finding rare Gasteromycetes, recently made a fine collection of twenty-two fructifications of this species on a sandy slope below Jan Swartsberg, 25 miles west of Williston, 30/vii/1956 (Acocks, A. 18917; PRE. 41592). The fungus was stated to be frequent in that locality.

The species is readily identifiable from Cunningham's description. Published photographs of the species show only one or two specimens, which are sometimes incomplete. Thus it seems desirable to publish the accompanying photograph (Fig. 1) which, in the original at least, gives a very good idea of the structure of this attractive and unmistakeable fungus.

The exoperidium is a sand-hyphal layer, fugitive except at the base. The endoperidium is umber brown, hard, papyraceous, polished, pitted, and dehisces by means of irregular splits from the apex downwards. The stipe, somewhat paler than the endoperidium, is socketed to the base of the peridium, and has a small semi-volvate mycelial pad at the base and also longitudinal striae and ill-defined appressed scales. The gleba is coloured deep umber with a purplish tinge. The capillitium threads are short, yellowish, non-septate, thin-walled, with characteristic short lateral branches with rounded ends. The spores are brown, smooth, subglobose, 4.5-6 $\mu$ diameter.

\section{Aseroë rubra La Bill. ex Fries.}

Although this species was described by Miss Bottomley (1948, p. 526), its occurrence in South Africa has hitherto been doubtful. The only known record was a specimen in Herb. Kew. collected by W. T. Saxton in Cape Town, which Miss Bottomley thought might have been confused with Anthurus archeri. It was therefore most interesting to receive indubitable specimens of Aseroë rubra collected by Mr. M. J. Howell in a plantation of Acacia mollissima at Otto's Bluff, Natal, on 2/ii/1957 (PRE. 41735), and again at Richmond, Natal, on 10/x/1957 (PRE. 41746). The first of these collections is illustrated in Fig. 3.

Miss E. L. Stephens informs me that 15 to 20 specimens of $A$. rubra were found growing close together on the farm Die Hoek, Swellendam C.P., by Miss D. Hermans and Mr. C. Steytler on $16 /$ iii / 1958 (Herb. E. L. Stephens No. 1845).

* Parts I and II of this paper appeared in Bothalia 6 (1951) 183-204 and Ibid. 6 (1956) 489-500 respectively. 


\section{Chlamydopus meyenianus (Klotzsch) Lloyd.}

There is only one previous record of this species for South Africa (Bottomley, 1948 , p. 625), for which no details of locality and collector were available. The species has been found again by Mr. J. P. H. Acocks on the ground at Pampoenpoort, C.P., 29/x/1954 (Acocks, 17842; PRE. 41007). It is illustrated in Fig. 2.

\section{Battarea stevenii (Liboschitz) Fries.}

This species is well illustrated and described by Miss Bottomley (1948, p. 620) who examined several South African collections. Four unusually fine specimens emerged in the grounds of the Division of Botany, Pretoria, in October 1950, (leg. P. H. B. Talbot; PRE. 39098) and provided an opportunity to take the accompanying photograph (Fig. 4). This supplements Miss Bottomley's illustrations by showing clearly the nature of the gleba before dehiscence of the peridium. The specimens appeared on a roadside which had been filled in a few months previously with very hard soil containing large pieces of shale, which were lifted and pushed aside by the fungus as it broke through the surface. About half of the stipe was underground. The fungus has not been seen there since.

\section{Helicosporium aureum (Corda) Linder.}

This attractive species was collected by Dr. A. L. James on a beam of imported southern pine which had been stacked for sixteen months in the open at Brakpan Mines Ltd., 8/v/1952 (T.R.L. 2900; PRE. 41738). It is superbly illustrated by Linder (1929, p. 279).

The fungus forms an olive-yellowish, loose, cottony layer which is separable from the substratum. The conidiophores are erect, brown, septate, 300-400-(700) $\mu$ in length and 6-7 $\mu$ wide at the base, tapering and becoming paler towards the apex. They are simple at first but later branch at right angles in the upper half to two-thirds of the conidiophore. Conidia are borne pleurogenously on hyaline bladder-like swellings, 6-9 $\mu$ long, which arise laterally on the lower part of the conidiophores. The conidia are hyaline to very pale yellowish, indistinctly multiseptate, coiled $3 \frac{1}{2}$ times in one plane. The coiled conidium is up to $22 \mu$ in diameter and its filament is 1-2 $\mu$ wide.

Among the helicosporous fungi imperfecti this species is easily recognised by its erect brown conidiophores which branch above at right angles, and by its coiled conidia borne on terminal spicules of bladders which occupy the lower part of the conidiophore.

\section{Tilletia ehrhartae sp. nov.}

Sori nigri in ovariis Ehrhartae calycinae. Sporae verrucosae fuscae globosae vel subglobosae, 19-24 $\mu$ diam.; verrucae rotundae ad $1.5 \mu$ altae. Typus PRE. 41604, leg. R. Story (6006).

Sori black, occupying the ovaries of Ehrharta calycina; spores dark-coloured, globose to subglobose, 19-24 $\mu$ diam., including the verrucose epispore composed of rounded warts up to $1.5 \mu$ high. Type R. Story (6006), on Ehrharta calycina, Nature Reserve, Lambert's Bay, Clanwilliam distr., Oct., 1956.

Dr. M. B. Ellis of the Commonwealth Mycological Institute has favoured me by comparing this collection with the type of Tilletia verrucosa Cooke \& Massee, the only other Tilletia yet reported on Ehrharta (Zundel, 1953, p. 301). In T. verrucosa the spores are 20-24 $\mu$ diam. (including the warts); they are very much paler than those of $T$. ehrhartae and the warts are $3-4 \mu$ long and acute at their tips. The contents of the sori are also much paler in $T$. verrucosa. 
7. Thecaphora bulbinellae sp. nov.

Sori in floribus celati ovaria perdentes; Cumulus sporarum granulosus niger; Columella nulla; Glomeruli sporarum stabili fusci subglobosi vel ellipsoidei, 24-54 $\mu$ diam., sporis 20 vel multis; Sporae globosae vel subglobosae vel ellipsoideae vel nonnihil angulatae, $(4 \cdot 6)-7 \cdot 7-12 \cdot 3 \mu$ maximo diametro, leves fuscae crasse tunicatae; Epispora crassitudine 0.5-1.5 $\mu$.

Sori enclosed by the flowers and destroying the ovaries. Spore mass granular, black. Columella absent. Spore-balls permanent, brown, subglobose to ellipsoid, 24-54 $\mu$ diam., containing from 20 to numerous spores. Spores firmly united, globose, subglobose, ellipsoid or somewhat angular, $(4 \cdot 6)-7 \cdot 7-12 \cdot 3 \mu$ in greatest diameter, yellow-brown to reddish-brown, thick-walled, the epispore 0.5-1.5 $\mu$ thick, smooth on both the united and free faces of the spores. On Liliaceae: Type PRE. 41745, leg. J. Toxopeus on Bulbinella setosa (Willd.) Dur. \& Schinz, Struben's Valley, Pretoria, 24 vi $/ 57$.

\section{Literature Cited.}

Botтomley, A. M........... (1948). The Gasteromycetes of South Africa. Bothalia 4, p. 473.

Cunningham, G. H......... (1944). The Gasteromycetes of Australia and New Zealand, p. 190.

Linder, D. H............. (1929). A Monograph of the Helicosporous Fungi Imperfecti. Ann. Mo. Bot. Gard. 16, p. 279.

Lloyd, C. G.............. (1923). Mycological Notes 7, p. 1173.

Zundel, G. L............ (1953). Ustilaginales of the World, p. 301. 



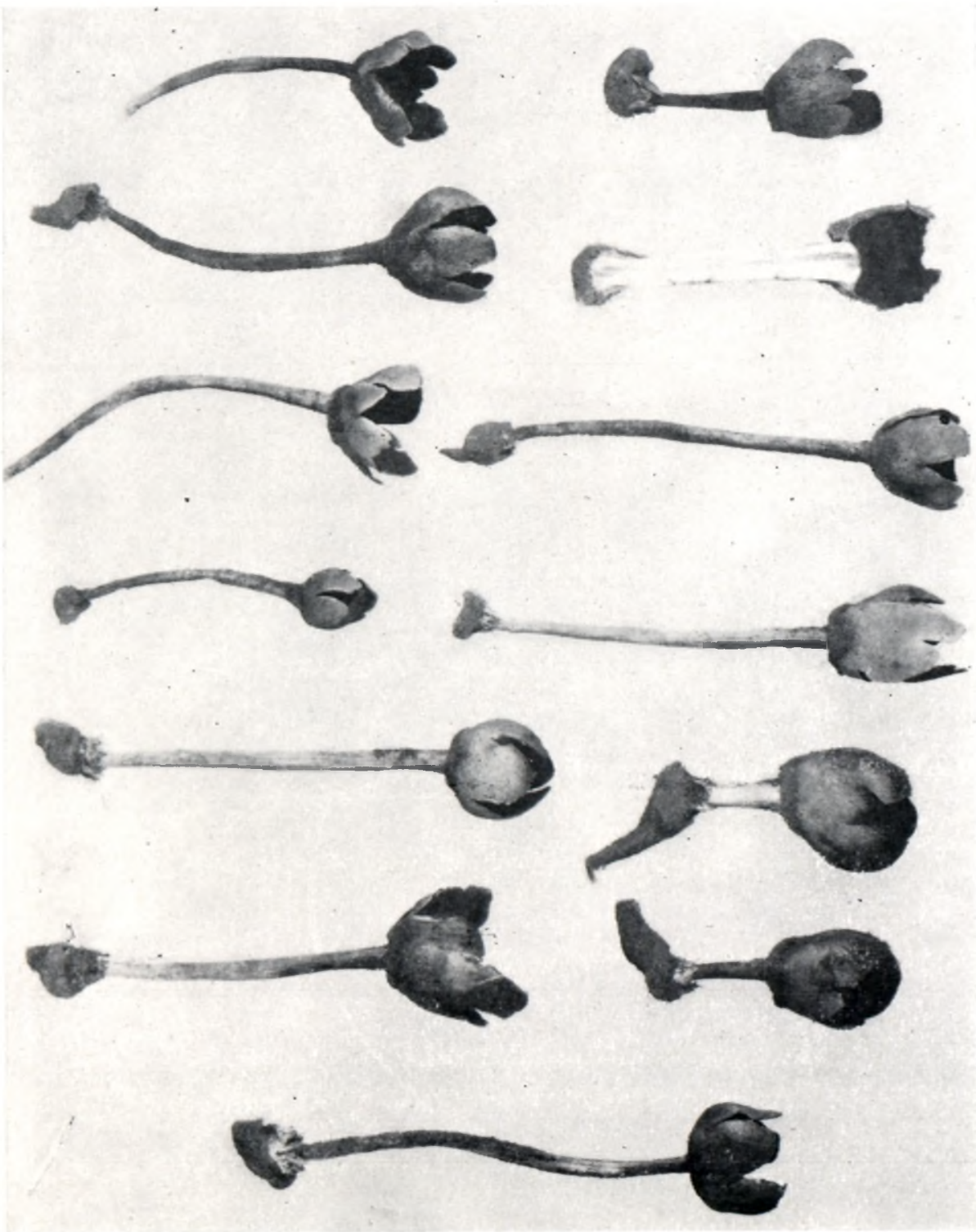

FIG. 1.-Schizostoma laceratum $\times 5 / 6$.

[Photo: H. King. 

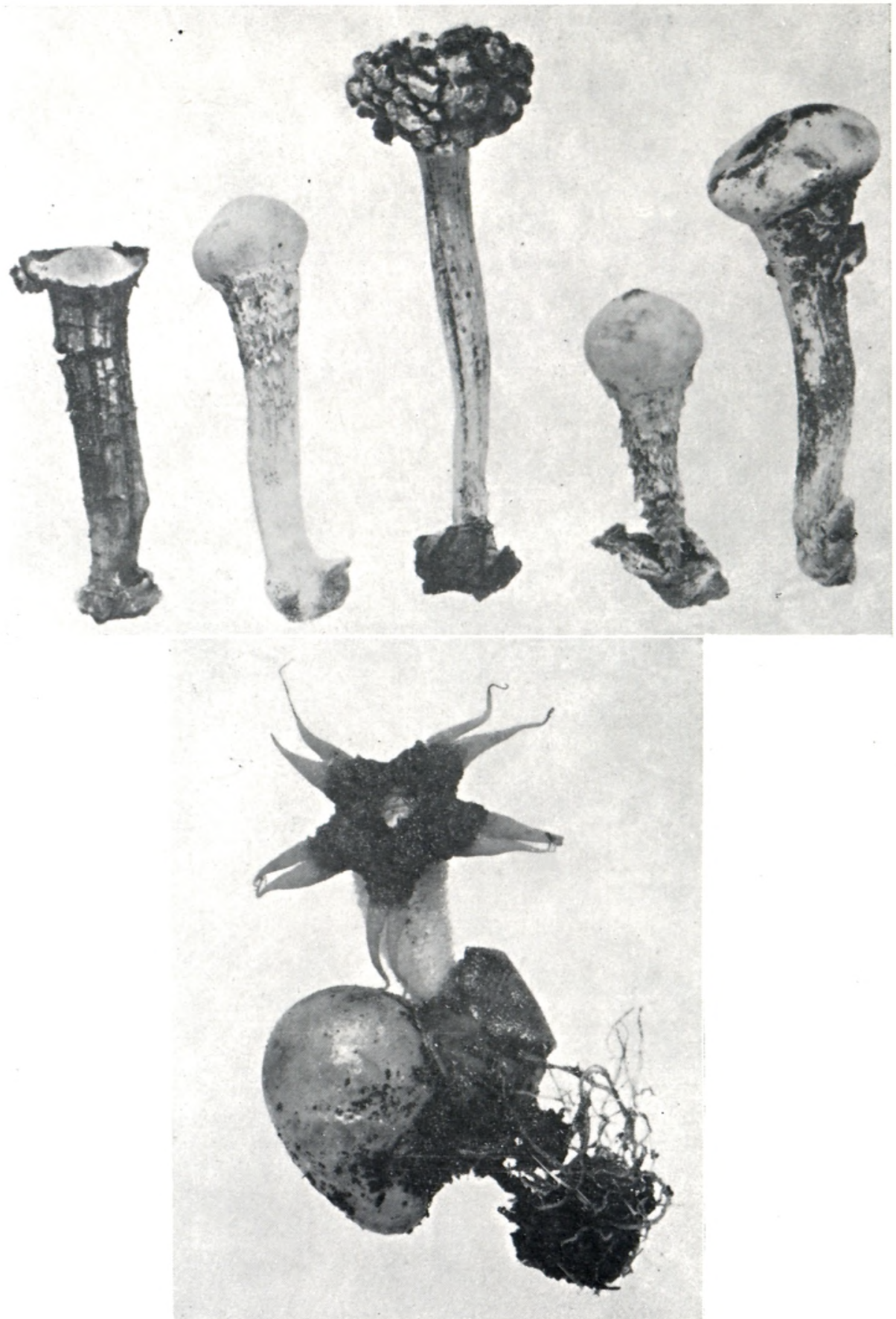

Above: Fig. 2.-Chlamydopus meyenianus $\times 1$. Below: Fig. 3.-Aseroë rubra $\times 1$.

[Photo: J. Reyburn. [Photo: J. Reyburn. 


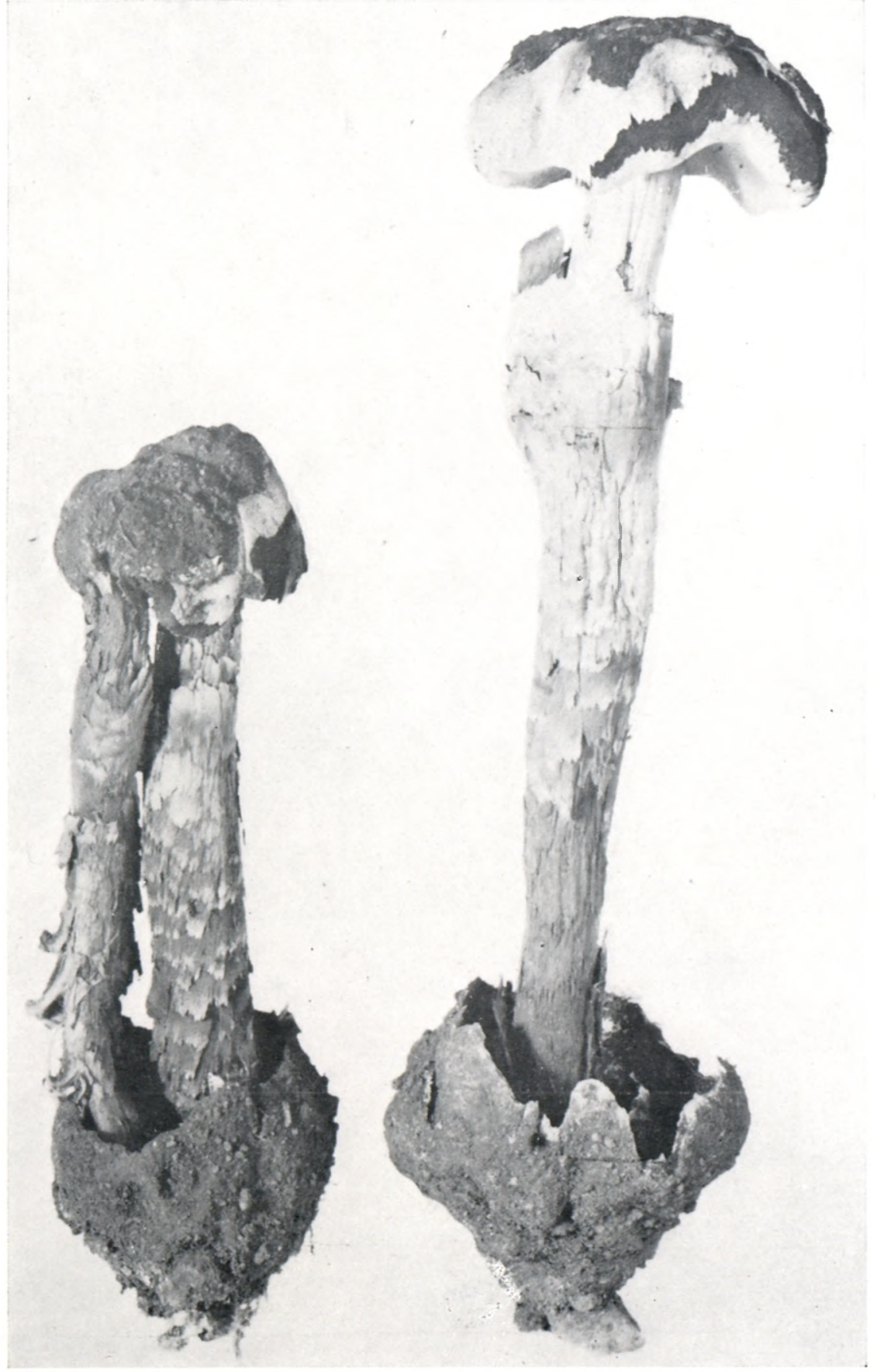

FIG. 4.-Battarea stevenii $\times 1 / 2$.

[Photo: H. King. 
